\title{
The Ig1/2 Domain of MuSK Binds to Muscle Surface and Is Involved in Acetylcholine Receptor Clustering
}

\author{
Qiang Wang ${ }^{\mathrm{a}, \mathrm{b}}$ Bin Zhang ${ }^{\mathrm{a}}$ Ye Elaine Wang ${ }^{\mathrm{a}}$ Wen-Cheng Xiong ${ }^{\mathrm{a}}{\text { Lin } \mathrm{Mei}^{\mathrm{a}}}^{\mathrm{a}}$ \\ a Program of Developmental Neurobiology, Institute of Molecular Medicine and Genetics and Department \\ of Neurology, Medical College of Georgia, Augusta, Ga., and ${ }^{b}$ Department of Neuroscience, Johns Hopkins \\ University, Baltimore, Md., USA
}

\section{Key Words}

MuSK $\cdot$ Ectodomain $\cdot$ Agrin $\cdot$ Acetylcholine receptor •

Binding $\cdot$ Neuromuscular junction

\begin{abstract}
The neuromuscular junction, the synapse between motor neurons and muscle cells, serves as an excellent model for studying synapse formation. Agrin is believed to be released by motor neurons to induce postsynaptic differentiation at the neuromuscular junction. MuSK, a receptor tyrosine kinase, appears to be a key component of the agrin receptor complex. However, how agrin activates MuSK remains unclear. To address this question, we characterized the binding of the MuSK extracellular region to the muscle cell surface. The MuSK ectodomain was found to bind to muscle cells in a manner dependent on stimulation with neural agrin. Moreover, the binding was myotube specific and appeared to be mediated by two regions in the MuSK: one region containing the first and second immunoglobin domains and the other containing the cysteine-rich domain. Importantly, recombinant proteins containing the binding activity can block fulllength MuSK binding to muscle cells and agrin-induced AChR clustering. These results suggest that the $\lg 1 / 2$ domain of MuSK is involved in AChR clustering by binding to the muscle surface.

Copyright $\odot 2008$ S. Karger AG, Basel
\end{abstract}

\section{KARGER}

Fax +41613061234 E-Mail karger@karger.ch www.karger.com

\section{Introduction}

Brain functions rely on the synapses where two neurons contact one another. Proteins essential for neurotransmission are concentrated at the postsynaptic membrane to ensure fast, reliable, and efficient communication between the neurons. However, the molecular mechanisms of the synaptic protein concentration are not well understood. The neuromuscular junction (NMJ) is a peripheral cholinergic synapse that conveys signals from the motor neurons to the muscle cells. It has served as an informative model of synaptogenesis because of its simplicity and easy accessibility $[1,2]$. NMJ formation requires communication between presynaptic motoneurons and postsynaptic muscle fibers $[1,3]$. The acetylcholine receptor $(\mathrm{AChR})$ concentration requires three molecules: agrin, a glycoprotein believed to be utilized by motor neurons to direct postsynaptic differentiation [4]; MuSK, a type I receptor tyrosine kinase that can be activated by agrin [5-7]; and rapsyn, an intracellular protein that interacts with the $\mathrm{AChR}[8,9]$.

Q.W. and B.Z. contributed equally.
Dr. Lin Mei

Program of Developmental Neurobiology

Institute of Molecular Medicine and Genetics and Department of Neurology

Medical College of Georgia, 1120 15th Street, Augusta, GA 30912 (USA)

Tel. +1 706721 8775, Fax +1 706721 8685, E-Mail lmei@mcg.edu 
MuSK appears to be involved in every aspect of NMJ development and maintenance [10-12]. MuSK mutant mice do not form the NMJ and prepattern of aneural AChR-rich sites in the central region, even in the absence of AChR dispersing signals from the motonerves to either the ChAT or HB9 mutant background $[11,12]$. Agrin mutant mice, however, appear to be prepatterned when ChAT or HB9 is deficient. These observations provide genetic evidence that agrin functions upstream of MuSK. Moreover, agrin induces rapid tyrosine phosphorylation of MuSK in cultured muscle cells [5]. Agrin is no longer able to induce AChR clusters in MuSK-/- myotubes and the agrin sensitivity can be restored by the introduction of wild-type MuSK $[5,13]$. In addition, agrin-induced AChR clustering can be inhibited by a dominant-negative form of MuSK. These results suggest that MuSK may function as a receptor for agrin. However, there is no evidence that the two proteins interact directly. A hypothetical molecule MASC (myotube-associated specificity component) was thus proposed to serve as a binding partner for agrin to transduce signals to MuSK [5]. It may be either a co-ligand or a co-receptor for MuSK and agrin.

To understand how MuSK is regulated, we characterized the binding of the MuSK ectodomain to the muscle surface. We provide evidence that myotubes express binding activity for the MuSK ectodomain. This activity was enhanced by neural but not muscle agrin. The regions in the MuSK ectodomain necessary for muscle surface binding were identified and the biochemical properties of the binding activity were characterized. Our data suggest a role of this binding activity in regulating agrininduced AChR clustering.

\section{Materials and Methods}

\section{Reagents}

Taq polymerase, T4 ligase, and restriction enzymes were purchased from Promega (Madison, Wisc., USA). Horseradish peroxidase-conjugated donkey anti-mouse and goat anti-rabbit antibodies and enhanced chemifluoresent (ECL) reagents for Western blotting were purchased from Amersham. Oligonucleotides were synthesized by Integrated DNA Technology (Coralville, Iowa, USA). Unless otherwise specified, all chemicals were from Sigma-Aldrich. MuSK-/- and control cell lines were a kind gift of Dr. David Glass (Regeneron Pharmaceuticals, Tarrytown, N.Y., USA). Agrin constructs were gifts from Zach Hall [14].

\section{Constructs}

The entire MuSK ectodomain and its derived fragments were generated by high-fidelity PCR using mouse MuSK as the template (Genbank Accession U37709). For alkaline phosphatase (AP) fusion proteins, DNAs were subcloned into pAPtagAP-5 vector at XhoI and XbaI (GenHunter, Nashville, Tenn., USA). The amino acid residues are aa 1-483 for MuSKext, aa 1-101 for Ig1, aa $1-197$ for $\operatorname{Ig} 1 / 2$, aa $1-289$ for $\operatorname{Ig} 1 / 2 / 3$ and aa $307-483$ for CRD. For FLAG-MuSK constructs, DNAs were subcloned in EcoRI/ $\mathrm{XbaI}$ sites in pFlag-CMV1 downstream of an artificial signal peptide sequence and a FLAG epitope.

\section{Cell Culture and Transfection}

Primary muscle cells were cultured from E19 rat hind leg muscles following a previously described protocol [15]. Briefly, muscles were isolated from hind legs, tweezed apart and incubated in $0.25 \%$ trypsin at $37^{\circ} \mathrm{C}$ for $40 \mathrm{~min}$. Following incubation, primary growth medium (10\% horse serum, 10\% fetal bovine serum, $2 \%$ chick embryo extract, $25 \mu \mathrm{g} / \mathrm{ml}$ gentamicin in DMEM) was added to the trypsinized muscle and triturate. The tissue/cell suspension was filtered through a 20-mesh nylon screen using a $50-\mathrm{ml}$ syringe. Cells were cultured on vitrogen-coated dishes at $1.5-2 \times$ $10^{6} / \mathrm{ml}$. MuSK-/- muscle cells were maintained in $33^{\circ} \mathrm{C}$ in growth medium (Dulbecco's modified Eagle's medium/F-12 3:1, 10\% fetal bovine serum, 20 units $/ \mathrm{ml}$ interferon- $\gamma$ ) and fused at $39^{\circ} \mathrm{C}$ in fusion medium ( $2 \%$ horse serum). C2C12, HEK293, and COS7 cells were cultured and/or transfected as previously described [16-18]. Calcium phosphate-mediated transfection was used except for MuSK-/- cells, which were transfected with the Fugene6 transfection reagent (Roche, Inc.) according to the manufacturer's instructions.

\section{AChR Clustering Assays}

C2C12 or MuSK-/- myotubes were treated with $10 \mathrm{ng} / \mathrm{ml}$ agrin (T1.4.8) for $18 \mathrm{~h}$ to induce AChR clusters [19]. After fixation in $2 \%$ paraformaldehyde for $30 \mathrm{~min}$, cells were incubated with 50 nM rhodamine-conjugated $\alpha$-bungarotoxin (R-BTX) (Molecular Probes) for $60 \mathrm{~min}$ to label AChR. After incubation with FITCconjugated secondary antibody, coverslips were mounted with VectaShield (Vector Laboratories, Inc.) and viewed under a Zeiss epifluoresence microscope. Images were collected with Openlab 3.0 software. AChR clusters whose diameters or longer axes were equal to or greater than $4 \mu \mathrm{m}$ were scored.

\section{Recombinant Protein Production and Purification}

To produce recombinant MuSK proteins, HEK293 were transfected with their respective plasmids. Twenty-four hours after transfection, cells were switched to Dulbecco's modified Eagle's medium containing $0.5 \%$ fetal bovine serum, which was collected every 2-3 days, twice. MuSK-AP fusion proteins, containing 6 His-tags encoded by pAPtagAP-5, were purified using BD TALON Resin (BD Biosciences) according to the manufacturer's instructions. MuSK-AP was measured by spectrophotometer at 405 $\mathrm{nm}$. To produce agrin, COS7 cells were transfected with their respective agrin constructs. Twenty-four hours after transfection, cells were switched to Dulbecco's modified Eagle's medium containing $0.5 \%$ fetal bovine serum. The medium was collected every 2-3 days, twice. Agrin was purified using BD TALON Resin. Media were pooled and the concentrated agrin was quantified by Western blotting. Conditioned medium from untransfected COS7 cells was used as control in all the experiments.

Cell-Surface-Binding Assay

Muscle cells, in 6-well dishes, were incubated at room temperature for $90 \mathrm{~min}$ and washed with cold HABH buffer $(0.5 \mathrm{mg} /$ 


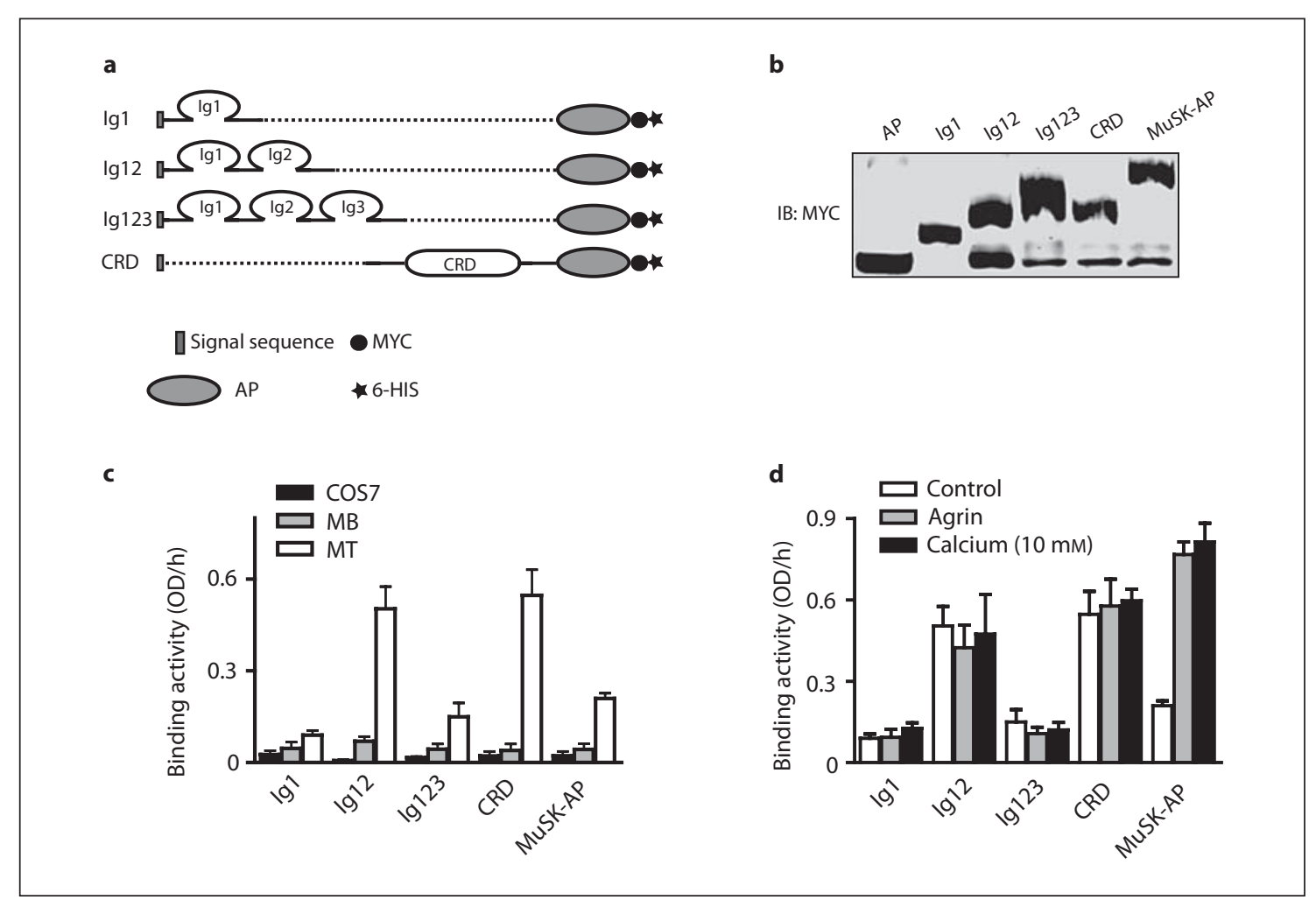

Fig. 1. Identification of domains in MuSK for interaction with muscle cells. a Diagrams of MuSK-AP containing different ectodomains. b Expression of MuSK ectodomains. Each recombinant protein migrated at the predicted molecular weight. c Ig1/2 and CRD bind to myotubes but not myoblasts and COS7 cells. All probes were used at $50 \mathrm{nM}$ in the experiments. $\mathbf{d}$ Ig1/2 and CRD bindings to myotubes were not enhanced by neural agrin $(10 \mathrm{nM})$ or calcium $\left(10 \mathrm{mM} \mathrm{CaCl}_{2}\right)$. Data are shown as mean $\pm \mathrm{SD}(\mathrm{n}=3)$. IB $=$ Immunoblotting; $\mathrm{MB}=\mathrm{myo}-$ blast; $\mathrm{MT}=$ myotube.

$\mathrm{ml}$ bovine serum albumin, $0.1 \% \mathrm{NaN}_{3}, 20 \mathrm{mM}$ HEPES, $\mathrm{pH}$ 7.0). Subsequently, cells were incubated with MuSK-AP fusion proteins at room temperature for $90 \mathrm{~min}$ in $\mathrm{HABH}$ buffer, washed with $\mathrm{HABH}$ buffer, and lysed in the lysis buffer (1\% Triton-X100, $10 \mathrm{mM}$ Tris, $\mathrm{pH}$ 8.0). Lysates were cleared by centrifugation $(12,000$ $\mathrm{rpm}, 5 \mathrm{~min}$ at room temperature) and incubated at $65^{\circ} \mathrm{C}$ for 10 min to inactivate endogenous AP. $100 \mu \mathrm{l}$ of resulting lysates was incubated with an equal volume of $2 \times \mathrm{AP}$ buffer $(66 \mathrm{mg} / \mathrm{ml} p$ nitrophenyl phosphate, $1 \mathrm{mM} \mathrm{MgCl}$, in $2 \mathrm{M}$ diethanolamine, $\mathrm{pH}$ 9.8). The AP activity was measured by the change in absorbance at $405 \mathrm{~nm}(\mathrm{OD} / \mathrm{h})$ using a multiwell plate reader.

\section{Results}

\section{Mapping MuSK-Binding Domains}

To better understand how the activity of MuSK is regulated, we sought to determine whether the ectodomain of MuSK binds to the muscle surface. The ectodomain was fused with human placental isozyme of AP (online suppl. fig. 1a, www.karger.com/doi/10.1159/000111567), which is heat-insensitive and thus different from the endogenous heat-sensitive isozyme. AP fusion proteins have been used for ligand-receptor interaction [20,21]. The ectodomain of MuSK was previously shown to be able to block agrin-induced AChR clustering [5]. In agreement with this observation, treatment of $\mathrm{C} 2 \mathrm{C} 12$ myotubes with MuSK-AP attenuated AChR clusters in response to agrin (online suppl. fig. 1b, www.karger.com/ doi/10.1159/000111567), but not with the medium collected from control 293 cells. We were able to detect binding activity in muscle cells using MuSK-AP, which has the following characteristics. First, it was myotube-specific. MuSK-AP binding to myoblasts or COS7 cells was minimal, if any, regardless of the presence or absence of neural agrin (online suppl.fig. 2a, www.karger.com/doi/10.1159/ 000111567). Second, the effect is neural agrin-specific. MuSK-AP binding remained unchanged in myotubes treated with T1 muscle agrin (online suppl. fig. $2 \mathrm{~b}$ and 2c, www.karger.com/doi/10.1159/000111567). However, 
Fig. 2. Characterization of binding activities of MuSK-AP, Ig1/2, and CRD. a Attenuated MuSK-AP binding to the muscle cell surface by Ig1/2. C2C12 muscle cells were incubated with FLAG-tagged Ig1/2 for $1 \mathrm{~h}$ prior to incubating with MuSK-AP and neural agrin (T1.4.8). b FLAG-tagged CRD inhibited MuSK-AP binding to the muscle cell surface. c MuSK-AP binding to muscle cell surface was blocked by $\operatorname{Ig} 1 / 2$ and CRD. C2C12 cells were incubated with various concentrations of FLAG$\operatorname{Ig} 1 / 2$ and CRD for $1 \mathrm{~h}$ prior to incubating with MuSK-AP and neural agrin. d No effect on Ig1/2 binding to muscle cell surface by CRD. FLAG-tagged CRD was added to C2C12 cultures for $1 \mathrm{~h}$ prior to adding Ig1/2-AP fusion protein to the culture. Data are shown as mean $\pm \operatorname{SD}(\mathrm{n}=3)$.

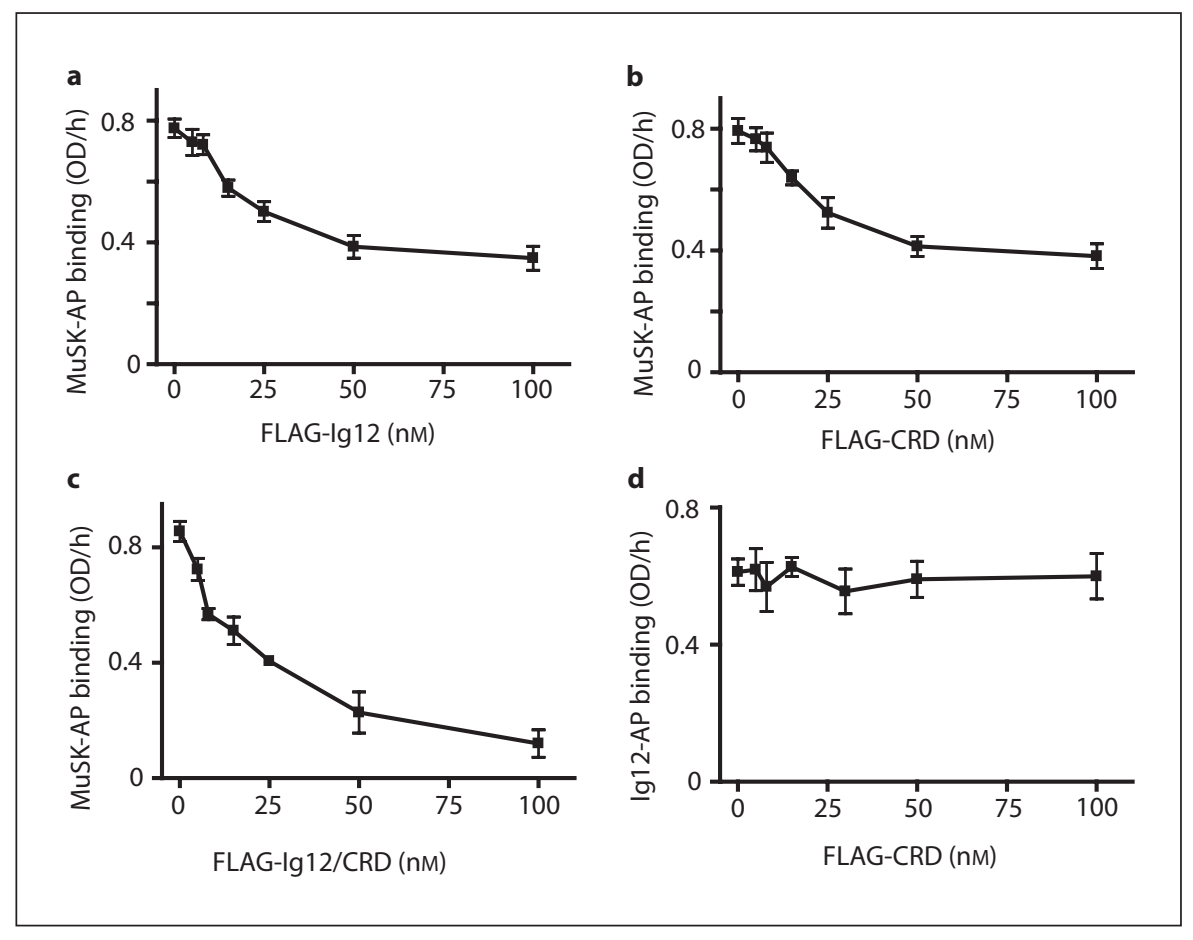

agrin did not appear to change the $\mathrm{EC}_{50}$ values, although it increases the maximal binding, suggesting no change in MuSK-AP-binding affinity (online suppl. fig. 2b, www. karger.com/doi/10.1159/000111567).

The MuSK ectodomain has three Ig-like domains (Ig1-3) in the N-terminal region and one cysteine-rich domain (CRD) close to the transmembrane domain. Ig1/2 has been shown to be critical for agrin induction of AChR clusters [13]. To identify the domains for binding to muscle surface, we generated AP fusion proteins containing various combinations of Ig and CRD domains (fig. 1a), which were expressed as secreted proteins at predicted molecular weights (fig. 1b). As shown in figure 1c, constructs containing both Ig1 and Ig2 (such as Ig1/2, Ig1/2/3, and MuSK-AP) or CRD alone exhibited myotube-specific binding, suggesting that there are two binding motifs in the MuSK ectodomain. Ig1 alone did not appear to be sufficient to bind to the myotube surface, suggesting that the binding activity requires the participation of Ig2. The binding activity of either Ig1/2 or CRD, however, showed higher affinities than MuSK-AP. Moreover, unlike MuSK-AP, the binding of Ig1/2, Ig1/2/3 or CRD to myotubes was not enhanced by neural agrin or calcium (fig. 1d). These results could suggest a conformation-dependent regulation of MuSK binding to the muscle surface, which requires both Ig1/2 and CRD.
Next, we determined if Ig1/2 and CRD bind to the same activity as the full-length ectodomain. If so, they should be able to compete for the binding activity and thus may suppress agrin-induced AChR clustering. We first examined whether Ig1/2 and/or CRD inhibit MuSKAP binding to myotubes. As shown in figure 2a, b, FLAGIg1/2 and FLAG-CRD were able to suppress MuSK-AP binding individually. Although the inhibitory effects were dose dependent, a plateau was reached at $50 \mathrm{nM}$. Remarkably, the addition of both Ig1/2 and CRD at the same time further suppressed MuSK-AP binding (fig. 2c). Moreover, CRD at increasing concentrations had little effect on Ig1/2 binding to myotubes (fig. 2d). These results suggest that the MuSK ectodomain has two binding motifs; each binds to a different binding activity on the muscle surface. To study the functional relevance of Ig1/2 and CRD binding to myotubes, we investigate whether they could inhibit agrin-induced AChR clustering. As shown in figure 3, treatment with MuSK-AP inhibited receptor clustering, in agreement with previously findings (online suppl. fig. 1, www.karger.com/ doi/10.1159/000111567) [5]. Treatment with Ig1/2, consistent with an earlier report that Ig1/2 is essential for MuSKmediated AChR clustering, also inhibited receptor clustering. However, CRD appeared to have little effect on receptor clusters. 


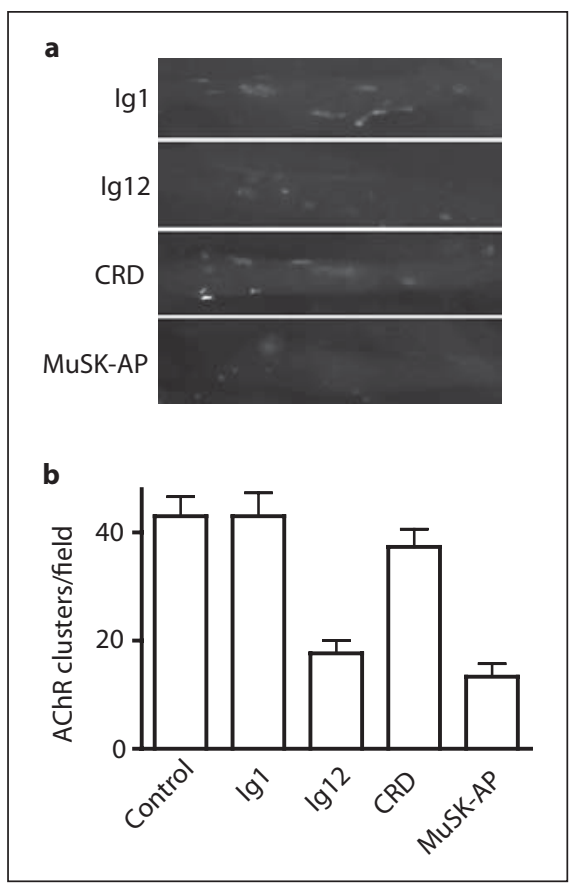

Fig. 3. Inhibition of agrin-induced $A C h R$ clusters by different MuSK ectodomains. The indicated MuSK ectodomains were added to $\mathrm{C} 2 \mathrm{C} 12$ myotube cultures before T1.4.8 (10 nM) treatment. Myotubes were stained with R-BTX $12 \mathrm{~h}$ after agrin treatment. AChR clusters were counted under a $\times 40$ objective field. Three random fields were chosen from each of three independent cultures. R-BTX $=$ Rhodamine-conjugated $\alpha$-bungarotoxin. a Representative images from each experimental group. b Quantitative data of (a). Data are shown as mean $\pm \mathrm{SD}(\mathrm{n}=3),{ }^{*} \mathrm{p}<$ 0.05 .

\section{Regulation of MuSK Binding to the Muscle Cell Surface by Calcium}

Calcium is necessary for AChR clustering. Interference with the intra- and extracellular calcium concentration alters agrin-induced AChR clusters [22, 23]. Moreover, the binding of agrin to the muscle cell surface is elevated by calcium $[24,25]$. In addition, calcium seems to be able to induce AChR clusters in the absence of exogenous agrin, and this effect by calcium and agrin-induction is additive $[26,27]$. We tested whether binding of the MuSK ectodomain to muscle cells is regulated by extracellular calcium. In the absence of calcium, binding of C2C12 myotubes to MuSK-AP was minimal, which is not consistently different from AP alone (fig. 4a). The binding increased with the increasing calcium concentrations in the medium. In comparison with the control, a significant increase was observed at $5 \mathrm{~mm}$ calcium (fig. 4a). The potentiation effect of calcium is dose-dependent and saturable. It is also specific for MuSK-AP, because AP binding to the muscle cell surface was not sensitive to calcium even at high concentrations (fig. 4a). Moreover, the effect of calcium is myotube specific in that neither COS7 cells nor myoblasts showed any MuSK-AP-binding activity in the presence of elevated calcium levels (fig. 4b).

Because MuSK-AP binding to the myotube surface is regulated by agrin and calcium, we next investigated the relationship between the two stimuli. MuSK-AP binding was assayed in cells in the presence of agrin or calcium, or both, at concentrations close to the respective $\mathrm{EC}_{50}$

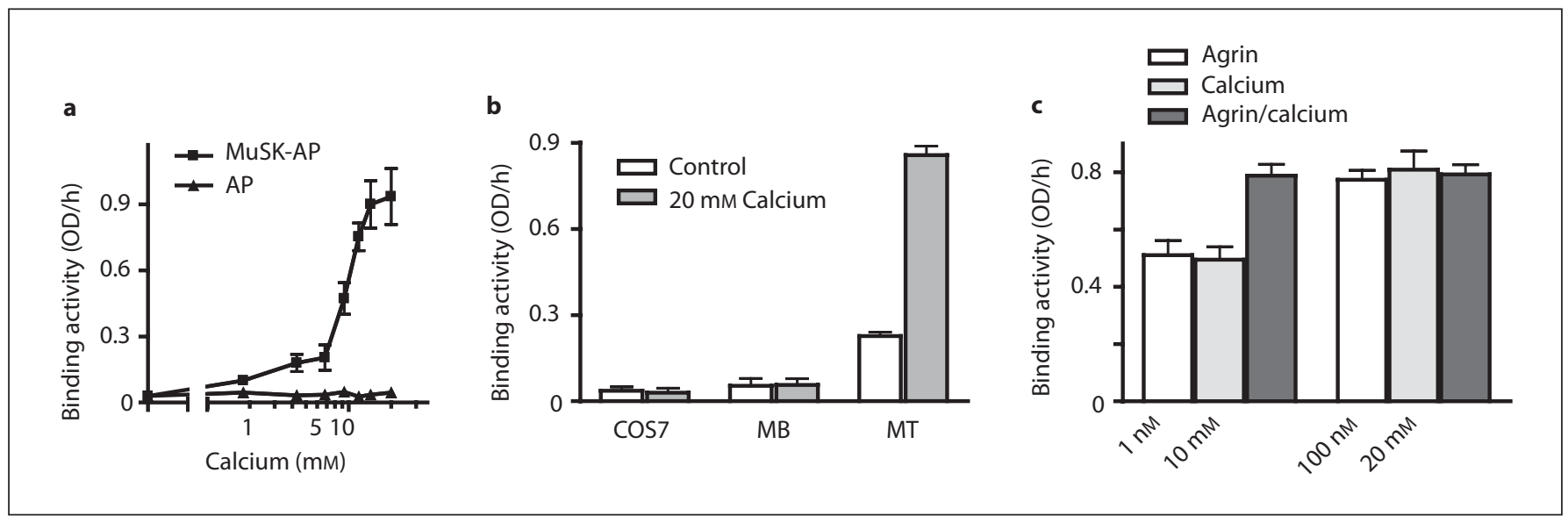

Fig. 4. MuSK-AP binding to muscle cells depends on calcium. a $\mathrm{C} 2 \mathrm{C} 12$ myotubes were incubated with AP or MuSK-AP in the presence of different concentrations of calcium. b Calcium enhanced MuSK-AP binding to myotubes but not myoblasts or COS7 cells. $\mathrm{MB}=$ Myoblast $\mathrm{MT}=$ myotube $\mathbf{c}$ Calcium and agrin increased MuSK-AP bindings to the muscle cell surface were additive at low concentrations ( $1 \mathrm{nM}$ agrin and $10 \mathrm{~mm}$ calcium) and co-saturable at high concentrations (100 $\mathrm{nm}$ agrin and $20 \mathrm{~mm}$ calcium). Data are shown as mean $\pm \operatorname{SD}(n=3)$. 
( $1 \mathrm{nM}$ agrin and $10 \mathrm{mM}$ calcium), allowing for reliable characterization of the effect by a single factor and of a possible cooperative effect. As shown in figure $4 c$, the addition of both agrin and calcium generated an additive effect. Note that the effect was comparable to the maximal response by either agrin or calcium at higher concentrations, and a further increase in agrin and calcium concentration did not elevate MuSK-AP binding. These results suggest that agrin and calcium may potentiate MuSK-AP binding via similar mechanisms.

\section{Trypsin Treatment Eliminates MuSK Binding to Muscle Cells}

To understand the biochemical nature of MuSK-binding activity on the muscle surface, $\mathrm{C} 2 \mathrm{C} 12$ myotubes were treated with various enzymes that are known to modify extracellular proteins. Treatment with trypsin at a concentration that did not alter cell morphology and viability decreased MuSK-AP binding to the muscle surface (fig. 5a). This result suggests the involvement of a protein component in MuSK-binding activity. The identity of this protein awaits further characterization. However, it did not appear to be a GPI-linked protein because it was unaffected by treatment with PI-PLC (fig. 5a). Moreover, treatment of muscle cells with heparantinase, chondroitinase or neuraminidase had little effect on MuSK-AP binding, suggesting that heparin sulfate proteoglycan (HSPG), chondroitin sulfate proteoglycan (CSPG) or sialic acid may not be critical components contributing to MuSK surface-binding activity (fig. 5a). MuSK is a type I receptor tyrosine kinase that is known to form homodimers. The exogenous MuSK-AP may form a dimer with endogenous MuSK. To exclude this possibility, we characterized MuSK-AP binding to MuSK-/- myotubes. MuSK-AP bound to MuSK-/- myotubes equally well and the binding activity was also enhanced by neural agrin and calcium (fig. 5b). Taken together, these results suggest that the MuSK ectodomain binds to a protein component on the muscle surface that is not MuSK itself.

\section{Discussion}

Although MuSK is essential for NMJ formation, how it is activated remains unclear. To this end, we investigated whether its extracellular region interacts with the muscle cell surface. We demonstrate that recombinant ectodomains of MuSK bound to intact muscle cells. The binding activity was myotube-specific and not present in myoblasts or non-muscle cells. It was enhanced by neu-

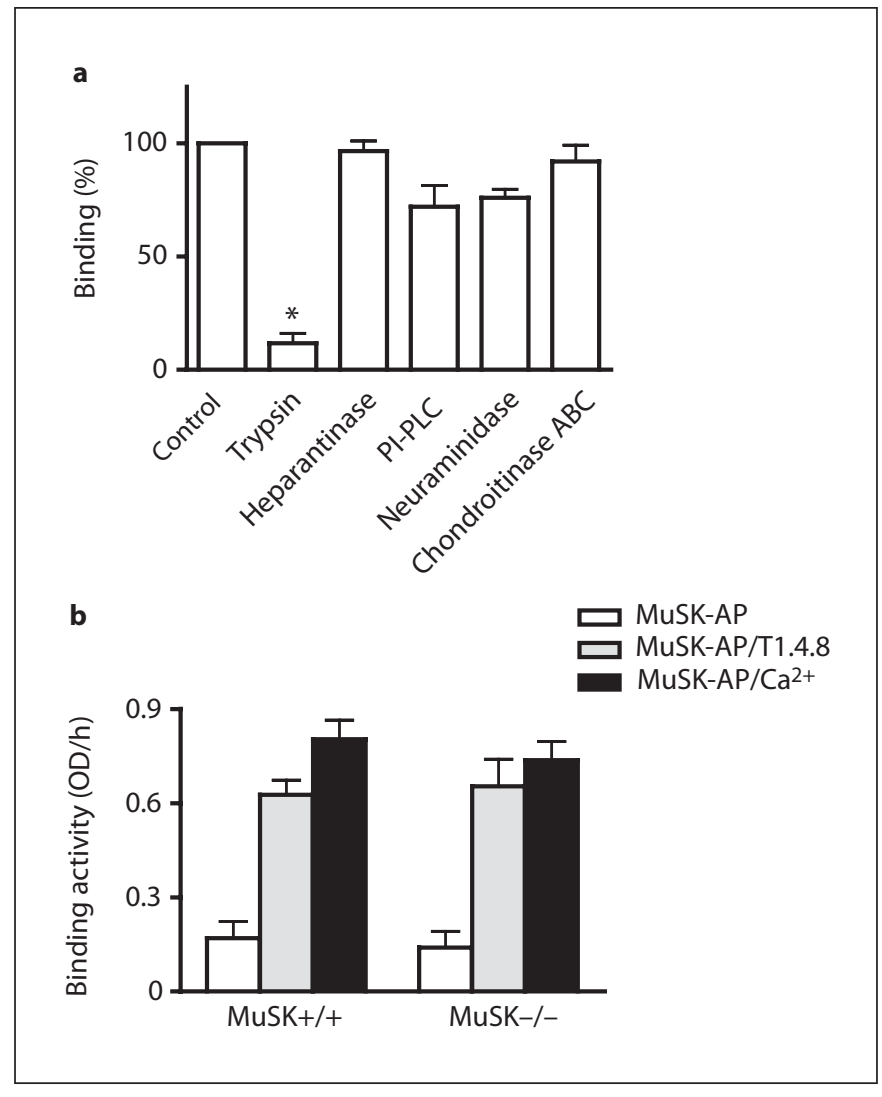

Fig. 5. MuSK-AP binding to the muscle cell surface is decreased by trypsin. a $\mathrm{C} 2 \mathrm{C} 12$ myotubes were treated with different enzymes $(0.01 \mathrm{mg} / \mathrm{ml}$ trypsin for $10 \mathrm{~min}, 0.2 \mathrm{U} / \mathrm{ml}$ heparantinase for $2 \mathrm{~h}, 0.1 \mathrm{U} / \mathrm{ml}$ chondroitinase ABC for $2 \mathrm{~h}, 1 \mathrm{U} / \mathrm{ml}$ PI-PLC for $2 \mathrm{~h}$, $0.2 \mathrm{U} / \mathrm{ml}$ neuraminidase for $2 \mathrm{~h}$, at $37^{\circ} \mathrm{C}$ ). The MuSK-AP binding in the presence of $10 \mathrm{nM}$ agrin was defined as $100 \%$. Data are shown as mean $\pm \mathrm{SD}(\mathrm{n}=3)$. b MuSK-/- or control muscle cells were incubated with $50 \mathrm{nM}$ MuSK-AP in the presence or absence of neural agrin $(10 \mathrm{nM})$ or calcium $(10 \mathrm{mM})$. Binding of MuSK-AP to MuSK-/- cells was comparable to that of wild-type muscle cells. Data are shown as mean $\pm \mathrm{SD}(\mathrm{n}=3)$.

ral, but not muscle, agrin and by calcium, which is known to regulate agrin binding to the muscle surface. The binding activity is located in two regions, each appearing to carry a distinct function. Importantly, recombinant proteins containing the binding activity can block full-length MuSK binding to muscle cells and agrin-induced AChR clustering. These results reveal a novel MuSK-binding activity on the muscle surface which may be necessary for agrin-induced AChR clustering.

MuSK-binding activity shares similar biochemical properties to that of agrin. First, as observed for agrinbinding activity [24], MuSK binding to the muscle sur- 
face was abolished by treatment of muscle cells with trypsin, suggesting an activity involving protein. Second, disruption of PI linkage with PI-PLC had little effect on MuSK binding to the muscle cells, suggesting that this binding activity is independent of GPI anchorage. Similar results were observed for the agrin-binding activity [24]. Third, binding of both the agrin and MuSK ectodomains to the muscle cell surface is enhanced by calcium [24]. The observation that muscle cells derived from MuSK mutant mice could bind to the ectodomains indicate that the binding activity does not appear to be MuSK itself that may interact with recombinant ectodomains via homodimerization. These results provide evidence for the existence of a protein that binds to the MuSK ectodomain, which may bridge the interaction with agrin. In support of this notion was the observation that MuSK binding to the muscle surface is enhanced by neural, not muscle, agrin (online suppl. fig. 2, www.karger.com/ doi/10.1159/000111567). This is consistent with the fact that neural agrin is two orders of magnitude more potent in inducing AChR clusters.

The MuSK extracellular region contains three Ig-like domains and a CRD. The binding activity appears to reside in two distinct regions: Ig1/2 and CRD. Interestingly, the binding affinity of each domain alone was higher than that of the full-length ectodomain (fig. 1), suggesting that a change in conformation is necessary for the ectodomain to bind to the muscle surface. In line with this notion was the observation that binding of Ig1/2 or CRD to the muscle surface was not regulated by neural agrin or calcium, which enhances the binding of the fulllength ectodomain (online suppl. fig. 2 and fig. 4, www. karger.com/doi/10.1159/000111567). A reasonable explanation could be that the binding site for neural agrin or the domain sensitive to calcium regulation is missing in individual Ig1/2 or CRD constructs. These observations support a working hypothesis that neural agrin and/or calcium interacts with the ectodomain to change its con- formation to allow for better binding to the muscle surface. Alternatively, calcium regulation may be an indirect effect. For example, agrin has been shown to bind to calcium with a conformational change [25]. Therefore, it is equally possible that such a calcium-agrin interaction is necessary for the regulation of the MuSK ectodomain binding to the muscle surface.

The lack of evidence for a direct association between agrin and MuSK leads to the hypothesis of a third component such as MASC in facilitating the agrin-MuSK interaction $[1,2]$. It may be either a co-ligand of agrin or a co-receptor for MuSK. However, the biochemical property of MASC has yet to be revealed. The binding activity on the muscle surface for MuSK ectodomains may be a candidate for MASC. First, the myotube-specific binding activity is regulated by agrin. Second, the ectodomain of MuSK can block agrin-mediated AChR clustering. The signaling mechanisms of the interleukin and GDNF families closely resemble this proposed hypothesis [28, 29]. More work is necessary to identify the molecular identity of the MuSK-binding activity.

In this paper, we provide evidence that different Ig domains of MuSK might have different binding abilities, and that this type of difference may work as a subtle regulation mechanism for the interaction of Ig superfamily proteins. Many Ig superfamily proteins, such as DSCAM, play important roles in neuron recognition and synaptogenesis [30]. Our work may be helpful to understand the complexity of Ig domain binding.

\section{Acknowledgements}

We are grateful to Dr. Zach Hall for original constructs of agrin and MuSK and to Dr. David Glass for the MuSK-/- and control cell lines. This work was support in part by grants from the NIH (L.M. and W.-C.X) and the Muscular Dystrophy Association (L.M.).
References
Sanes JR, Lichtman JW: Induction, assembly, maturation and maintenance of a postsynaptic apparatus. Nat Rev Neurosci 2001;2: 791-805.

-2 Sanes JR, Lichtman JW: Development of the vertebrate neuromuscular junction. Annu Rev Neurosci 1999;22:389-442.

3 Brandon EP, Lin W, D’Amour KA, Pizzo DP, Dominguez B, Sugiura Y, Thode S, Ko CP, Thal LJ, Gage FH, Lee KF: Aberrant patterning of neuromuscular synapses in choline acetyltransferase-deficient mice. J Neurosci 2003;23:539-549.

4 McMahan UJ: The agrin hypothesis. Cold Spring Harb Symp Quant Biol 1990;55:407418.

5 Glass DJ, Bowen DC, Stitt TN, Radziejewski C, Bruno J, Ryan TE, Gies DR, Shah S, Mattsson K, Burden SJ, DiStefano PS, Valenzuela DM, DeChiara TM, Yancopoulos GD: Agrin acts via a MuSK receptor complex. Cell 1996; 85:513-523. 
6 Glass DJ, Apel ED, Shah S, Bowen DC, DeChiara TM, Stitt TN, Sanes JR, Yancopoulos GD: Kinase domain of the musclespecific receptor tyrosine kinase (MuSK) is sufficient for phosphorylation but not clustering of acetylcholine receptors: required role for the MuSK ectodomain? Proc Natl Acad Sci USA 1997;94:8848-8853.

7 Jennings CG, Dyer SM, Burden SJ: Musclespecific trk-related receptor with a kringle domain defines a distinct class of receptor tyrosine kinases. Proc Natl Acad Sci USA 1993;90:2895-2899.

$>8$ Bloch RJ, Froehner SC: The relationship of the postsynaptic $43 \mathrm{~K}$ protein to acetylcholine receptors in receptor clusters isolated from cultured rat myotubes. J Cell Biol 1987; 104:645-654.

9 Frail DE, McLaughlin LL, Mudd J, Merlie JP: Identification of the mouse muscle 43,000dalton acetylcholine receptor-associated protein (RAPsyn) by cDNA cloning. J Biol Chem 1988;263:15602-15607.

-10 DeChiara TM, Bowen DC, Valenzuela DM, Simmons MV, Poueymirou WT, Thomas S, Kinetz E, Compton DL, Rojas E, Park JS, Smith C, DiStefano PS, Glass DJ, Burden SJ, Yancopoulos GD: The receptor tyrosine kinase MuSK is required for neuromuscular junction formation in vivo. Cell 1996;85: 501-512.

-11 Lin W, Burgess RW, Dominguez B, Pfaff SL, Sanes JR, Lee KF: Distinct roles of nerve and muscle in postsynaptic differentiation of the neuromuscular synapse. Nature 2001;410: 1057-1064.

-12 Yang X, Arber S, William C, Li L, Tanabe Y, Jessell TM, Birchmeier C, Burden SJ: Patterning of muscle acetylcholine receptor gene expression in the absence of motor innervation. Neuron 2001;30:399-410.
3 Zhou H, Glass DJ, Yancopoulos GD, Sanes JR: Distinct domains of MuSK mediate its abilities to induce and to associate with postsynaptic specializations. J Cell Biol 1999;146: 1133-1146.

14 Ferns M, Hoch W, Campanelli JT, Rupp F, Hall ZW, Scheller RH: RNA splicing regulates agrin-mediated acetylcholine receptor clustering activity on cultured myotubes. Neuron 1992;8:1079-1086.

15 Luo ZG, Wang Q, Zhou JZ, Wang J, Luo Z, Liu M, He X, Wynshaw-Boris A, Xiong WC, $\mathrm{Lu}$ B, Mei L: Regulation of AChR clustering by Dishevelled interacting with MuSK and PAK1. Neuron 2002;35:489-505.

16 Huang YZ, Won S, Ali DW, Wang Q, Tanowitz M, Du QS, Pelkey KA, Yang DJ, Xiong WC, Salter MW, Mei L: Regulation of neuregulin signaling by PSD-95 interacting with ErbB4 at CNS synapses. Neuron 2000;26: 443-455.

17 Si J, Wang Q, Mei L: Essential roles of c-JUN and c-JUN N-terminal kinase (JNK) in neuregulin-increased expression of the acetylcholine receptor epsilon-subunit. J Neurosci 1999; 19:8498-8508.

18 Won S, Si J, Colledge M, Ravichandran KS Froehner SC, Mei L: Neuregulin-increased expression of acetylcholine receptor epsilonsubunit gene requires ErbB interaction with Shc. J Neurochem 1999;73:2358-2368.

19 Ferns M, Deiner M, Hall Z: Agrin-induced acetylcholine receptor clustering in mammalian muscle requires tyrosine phosphorylation. J Cell Biol 1996;132:937-944.

20 Flanagan JG, Cheng HJ: Alkaline phosphatase fusion proteins for molecular characterization and cloning of receptors and their ligands. Methods Enzymol 2000;327:198210.

-21 Flanagan JG, Cheng HJ, Feldheim DA, Hattori M, Lu Q, Vanderhaeghen P: Alkaline phosphatase fusions of ligands or receptors as in situ probes for staining of cells, tissues, and embryos. Methods Enzymol 2000;327: 19-35.
22 Megeath LJ, Fallon JR: Intracellular calcium regulates agrin-induced acetylcholine receptor clustering. J Neurosci 1998;18:672678.

23 Megeath LJ, Kirber MT, Hopf C, Hoch W, Fallon JR: Calcium-dependent maintenance of agrin-induced postsynaptic specializations. Neuroscience 2003;122:659-668.

24 Ma J, Nastuk MA, McKechnie BA, Fallon JR: The agrin receptor. Localization in the postsynaptic membrane, interaction with agrin, and relationship to the acetylcholine receptor. J Biol Chem 1993;268:25108-25117.

$>25$ Tseng CN, Zhang L, Cascio M, Wang ZZ: Calcium plays a critical role in determining the acetylcholine receptor-clustering activities of alternatively spliced isoforms of agrin. J Biol Chem 2003;278:17236-17245.

-26 Grow WA, Ferns M, Gordon H: A mechanism for acetylcholine receptor clustering distinct from agrin signaling. Dev Neurosci 1999;21:436-443.

27 Grow WA, Ferns M, Gordon H: Agrin-independent activation of the agrin signal transduction pathway. J Neurobiol 1999;40:356365.

28 Davis S, Aldrich TH, Stahl N, Pan L, Taga T, Kishimoto T, Ip NY, Yancopoulos GD: LIFR beta and gp130 as heterodimerizing signal transducers of the tripartite CNTF receptor. Science 1993;260:1805-1808.

29 Stahl N, Yancopoulos GD: The alphas, betas, and kinases of cytokine receptor complexes. Cell 1993;74:587-590.

-30 Schmucker D, Flanagan JG: Generation of recognition diversity in the nervous system. Neuron 2004;44:219-222. 